\title{
総説
}

\section{In Place Leaching についで}

\author{
伊 藤 一 郎 ${ }^{1}$
}

UDC $622.791 / 793$

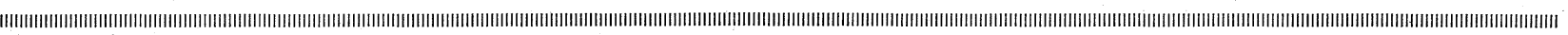

\section{1. 緒言}

よく知られているように, リーチング法は, もともと 浸出法と呼ばれている湿式治金の一技術であつて，対象 とする金属の種類に応じて適当な浸出液を用いて鉱石や 精鉣から有用金属成分を化学的に溶出し回収しょうとす る方法として用いられてきたものである。ところがその 後その応用範囲を拡張して, 低品位のために捨てられて いる廃石や選鉱後の廃滓などからの遺利の回収のために 利用することが考えられるようになつた。この場合，露 天掘で稼行している鉣山では，この方法を廃石や廃㳯に 適用して実施に移すための条件が比較的整えやすいとい ら事情にあつたために，主として露天掘鉱山においてこ の種の試みが多くなされてきた。このようにして発達し てきたのが heap leaching ${ }^{\text {a) } る い は ~ d u m p ~ l e a c h i n g ~}{ }^{\mathrm{b})}$ と呼ばれている方法であつて，今日においてもアメリカ を中心として世界各地の鉣山に抒いて数多く実施されて いる。ついで, このような heap leaching や dump leaching に関する研究と実績が積み重ねられていくに ともない, さらにその応用範囲を坑内にまで拡張し, 採 掘の際に残されている坑内の残鉱や低品位鈗に対して直 接リーチング法を適用して有利な稼行ができないかとい らことで, in place leaching ということが真剣に検討 されるよらになつてきたわけである。

以上のことから明らかなように, in place leaching (in situ leaching と呼ばれることも多い) は，採掘し た鉱石を処理するのではなく，鉱床そのものに対して 直接リーチング法を適用して有用金属成分を溶液中に 浸出させ，それより回収しようとする技術である ${ }^{2} 。 一$ 方，技術的には同じような内容をもつたものに solution mining がある。これら両者の区別は必ずしも明確では ないが，たとえば Hunkin は，有価鉱物を母岩脈石中 から選択的に浸出する場合を in place leaching, イオ ウ，岩塩，カリ岩塩などに㧍ける場合のように，鉣物そ のものを液体として外にとり出し, 跡に大きな空洞を残 すような採掘法を solution mining として, 両者を区別 して考えているよらであるが ${ }^{3} ，$ このよらな定義の仕方

* 1973年 6 月 15 日受理

1. 正会員 工博 京都大学教授 工学部資源工学科
は両者の差をある程度明確に示している点で注目に值す る。

さて，わが国のみならず世界的にみても，金属鉱山業 界はいまやきわめて困難な情勢のもとにおかれている。 年々その度合を増しつつある採掘条件の悪化と人件費の 高騰に加えて, 公害防止に対する強い要請に対処してい かなければならない。一方，資源全体の問題としても， 再生の不可能な化石資源である金属鉱物資源は，需給が 現在のままの高度な伸び率で推移していくならば，あま り遠くない将来には当然涸渇してしまうであろらという ことが憂慮されている。このような業界として，あるい は資源問題全体としてかかえている問題はあまりにも大 きく，その解決には多方面の分野からの真剣な検討と協 力が必要なことはいうまでもないが, 技術的な側面から は資源の有効利用に関する新技術の開発を推進すること が，多少でも問題解決への糸口を与えうる可能性をもつ ものであることは否定できないことと考えられる。この ような意味において in place leaching の場合もその例 外ではない。

そこでこの総説においては, in place leaching につ いての研究や実施の現状について分析を試み, 今後の適 用に対する技術的な問題点について考察してみたいと思 ら。

\section{2. in place leaching の特徵}

in place leaching は, 一般的にはつぎのような工程 から成り立つていると考えてよい。すなおち，1）リー チングに適したように目的とする鉱床の条件を整えるた めの工程，2）鉱床内に浸出液を送り込み，目的とする 有用金属成分をそれに溶解させる工程（このようにして 生じた有用金属成分を含む溶液を貴液（pregnant solution）という)，3）貴液を集めて地上に設けた処理工場 に送る工程，4）処理工場において貴液から金属成分を 回収する工程，5）金属成分を回収した後の廃水を処理 する工程，である。

a)リーチングを行な5目的で低品位鉱石を採掘し，ここれらを規則正しく積み 上げた堆積層の上部から撒水してリーチングを行なら方法1)

b ) 採掘時の廃石あるいは選釷後の廃石, 廃涬を積み上げた堆積層に対してり ーチングを行なら方法 
しかし, 実際にある特定の鉣床に対してこの方法を適 用するまでには，直接その鉣床を対象として，あるいは 実験室において基礎的に研究し明らかにして打けなけれ ばならない問題が多い。その主なものをあげればつぎの とおりである。

1）対象とする鉣床内に含まれている各種の鉱物から の有用金属成分の浸出性

2）浸出液の流動に対する対象鉱床の特性，具体的に いえば, 鉱床のもつ透水係数, 溶液の流動経路, 溶液の 流れを制限してある特定の回収点に導きうる防壁となる ような不浸透性の岩石層などが存在するかどうかなどの 問題を含む。

3）貴液加ら有用金属成分を回収する湿式治金技術の 確立

さて，上記のような基礎的な研究の成果に基ゔき， in place leaching が有利に稼行された場合には, 以下 に示すような利点をもつているといわれている。

1）他のどのような採鉣法をとる場合に比べても，所 要労働力は少なく, 投資額, 操業費ともに少なくてすむ。

2）鉣床の条件にもよるが，一般的には操業までの起 業期間が短かい。

3）環境を污染することが少ない。

4) 保安上安全で，近づき得ない鉱床に対しても適用 できる。

5）ふつらの方法で開発した場合には必要となる廃石 や廃㳯の処理が不要である。

このように, in place leaching はらまく適用されれ ば数多くの利点をもつ有利な方法ではあるが，この方法 が成立するための基礎的な条件から考えれば明らかなよ うに，この方法はどのような鉣床に対しても普遍的に適 用できるわけではない。すなわち, 適用可能な鉱床とし ては，鉱床内の透水係数がある程度以上の值をもち，か つ浸出液の流動を所定の操業区域内に限定できるような 地質条件をもつ鉣床が望ましいといわれている。現在, in place leaching あるいは solution mining がもつと も多く実施され，また技術的にも多くの研究がなされて いるのはアメリカであると思われるが，この国において も，実際に in place leaching は銅鉱およびウラン鉣を 対象として,また solution mining はイオウ, カリ鉣, および岩塩に対して適用されているのみで, 他の鉣種に 対する適用は今後の問題として残されているようであ る。

\section{3 . in place leaching $の$ 基礎}

\section{$3 \cdot 1$ 鉱床中における流体の流動性}

in place leaching においては, 適当な方法で鉱床中 に供給した浸出液が釷体中を流下あるいは流動し，その 間に鉱石中に含まれている金属成分を溶出し貴液をつく
ることになる。したがつて，鉱床中における浸出液の流 動性の問題はきわめて重要な問題となる。

地層中に打りる流体の運動については, 地下水学, 農 業土木，石油工学などの分野で多くの研究がなされてき ているが，これらの研究においては，地層中に打ける流 体の運動はつぎの (1) 式で示される Darcy の法則にし たがうといら考えのもとに取り扱われているものが多 w。

$$
q=\frac{k A\left(P_{1}-P_{2}\right)}{\mu L}
$$

ただし， $q$ : 流動する流体の流量 $\left(\mathrm{cm}^{3} / \mathrm{sec}\right)$

$A:$ 流体の流動する断面積 $\left(\mathrm{cm}^{2}\right)$

$P_{1}-P_{2}:$ 圧力降下 $(\mathrm{atm})$

$\mu:$ 流体の粘性係数 (cp)

$L:$ 流体の流動距離 $(\mathrm{cm})$

（1）式に打ける比例定数 $k$ は透水係数 (coefficient of permeability）あるいは透水率（permeability）と呼ば れ，その単位は， $q=1 \mathrm{~cm}^{3} / \mathrm{sec}, A=1 \mathrm{~cm}^{2}, \mu=1 \mathrm{cp}$, $L=1 \mathrm{~cm}, P_{1}-P_{2}=1 \mathrm{~atm}$ である場合に $k=1$ darcy と 定義されている。また二方， $1 \mathrm{cp}=0.01 \mathrm{dyne} \cdot \mathrm{sec} / \mathrm{cm}^{2}$, $1 \mathrm{~atm}=1.0132 \times 10^{6} \mathrm{dyne} / \mathrm{cm}^{2}$ であるから， 1 darcy= $0.987 \times 10^{-8} \mathrm{~cm}^{2}$ とも書きかえられる。

さて, Darcyの法則は，水が線状流動 (laminar flow) をなす場合にかぎり適用されるもので，渦状流動 (turbulent flow）をなす場合には適用できない。また, Darcy の法則が適用される透水層は，透過していく水の線状流 動を阻害しない程度の，しかもできるだけ均一な粒径を もつ細砂から構成されており，さらに水の流動は渦状流 動を起さない程度の小さい流速のもとで行なわれなけれ ばならないといわれている4)。 dump leaching や heap leaching においては, 鉣石の堆積層そのものが比較的上 記の条件を満たしやすい状態にあると考えられるので， これらの場合における浸出液の流動については近似的に Darcy の法則にしたがうものとして取り扱つても大き な詰りはないものと思われる。また， solution mining の場合，あるいは in place leachingにおいても，いわ ゆる飽和浸出（saturated leaching）といわれている方 法が適用される場合のように，注入井あるいはその他の 方法により浸出液を鉱体内の一点あるいは数点に加圧注 入し，他の 1 本または数本の井戸から貴液をポンプアッ プするような場合の鉱床は，比較的溶解しやすい多孔性 の鉱床を対象とする場合が多いから，このような場合の 鉱床内の浸出液の流動についても基本的には Darcy の 法則にもとづいた考えが適用できるものと思われる。し かし; いわゆる不飽和浸出 (unsaturated leaching) 女 るいは film percolation といわれている方法により in place leaching が行なわれている場合は，採掘ずみの 鉱床や採掘後の崩落鉱床を対象にしている場合が多いの 
で，このような場合の鉣床内での浸出液の流動に対して Darcy の法則が適用できるかどらかは，対象となる個 々の鉱床の特性を考慮した慎重な配慮が望ましいと考え る。

しかし，いずれにしても，鉱床内における流体の流動 が皆無に近ければ in place leaching は実施不可能と考 えられるから，鉱床のもつ透水性は in place leaching の成否を決める重要な要素の一つとなる。この点に関し てアメリカでは, in place leaching を適用する釷床は 5 millidarcy 以上の透水係数をもつものが望ましいとい う考え方が提示されているが5 ，この值は，われわれが この問題を考える場合の一つの目安を与えるものとして 非常に参考になるものである。

つぎに，どのような方法でリーチングを行ならにして も，浸出液が鉱床内のどのような流路をとおり，ぞれだ けの量が流動していくかといらことも明らかにしておか なければならない問題である。この問題に関しては, 従 来は，たとえばトレーサを用いて流路の探索を行なつた り，また，供給した水量と回収した水量との関係から流 量を推定するなど，主として現場を対象とした実験的な 手段により検討がなされてきている。しかし，このよう な方法のみでは, 流路や流量に関するある程度の資料は 得ることができるにしても，鉱床内での実際に起こりう る水の挙動に関してより詳しい情報をらることはむずか しい。そこで最近になつて, 電子計算機を用いてシミュ レーションを行なうことにより, リーチングの際の鉱床 内に打ける水の挙動を解析的に研究しようといらことが 試みられるようになつてきた。この方法は, リーチング の対象となる鉱床を解析に適するよらにモデル化し, 用 いるリーチング法に応じて導かれた鉱床中に抢ける水の 運動を支配する偏微分方程式を鉱床の特性を考慮した条 件のもとで解くことにより解を求めようとするものであ る。したがつて, 対象鉣床やリーチングの方法をどのよ うにうまくモデル化するか，また，条件として与える鉣 床の特性にどのような值を用いるかなどによつて, 結果 の信頼性が異なつてくることになるが，これらが合理的 に設定された場合には，リーチングの際の鉱床内におけ る水の挙動に関してきわめて有用な資料を得ることがで きる。第 1 図はこのような研究の結果の一例を示したも のであつて ${ }^{6)}$, これは図の上部に示した長さ $25 \mathrm{ft}$ の溜 池から均質な堆積層中に一様に浸出液が流下供給されて いる heep leaching を対象にして, 堆積層のほぼ中央 部の図に点線で示した範囲に不浸透性の粘土層があつた 場合，この粘土層が堆積層中における浸出液の流動にど のような影響をおよぼすかを解析した結果のうち, 浸出 液を供給しはじめてから 9.51 時間経過した時点での状 態を示したものである。この解析は, 堆積層の空隙率は $30 \%$, その透水係数は $10 \mathrm{darcy}$, 堆積層の飽和圧力水頭

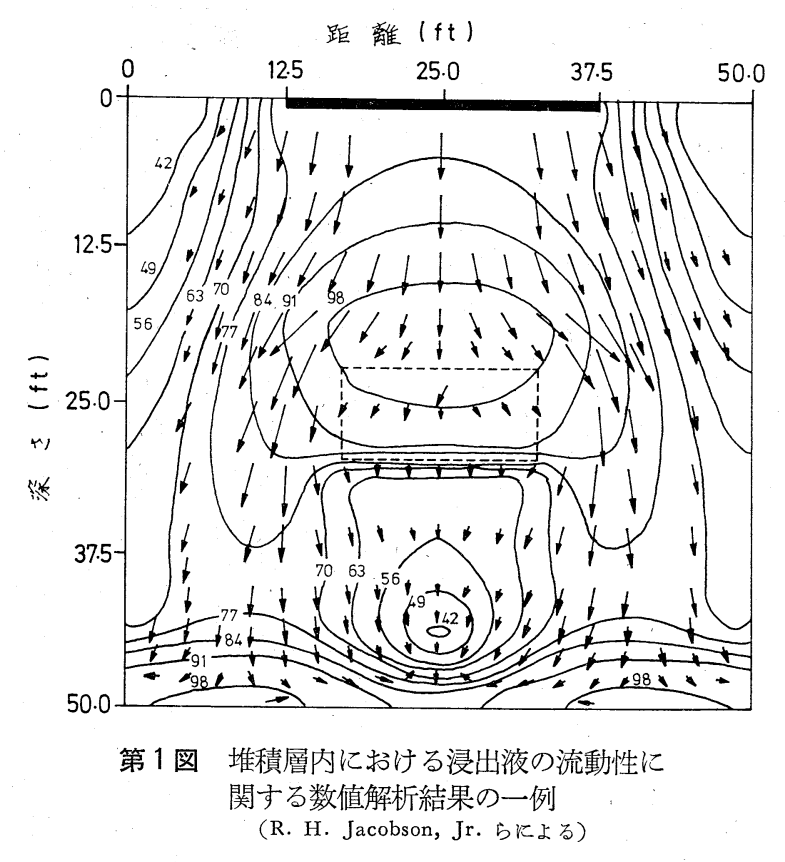

が $91.44 \mathrm{~cm}$ といら条件で行なわれているが，図中の矢 印はそれぞれの点における流線の方向，またその長さは 1 in が $0.02 \mathrm{~cm} / \mathrm{sec}$ の割合での流速を表わしており，さ らに等飽和率曲線が実線で示されている。したがつて， 各時点ごとにこのような図を作成して，それぞれを対比 しつつ検討すれば, 堆積層中における浸出液の挙動を適 確に推定することができ，これがリーチング法の設計や 実施に対してきわめて有用な資料として利用できるわけ である。

\section{$3 \cdot 2$ 鉱床の破砕と遮水壁の構築}

in place leaching に拉いては，鉱床内における浸出 液の流動性を高め, 浸出液と鉣石に含まれる金属成分と の接触面積を可能なかぎり大きくして反応を促進するた めに，リーチングの実施に先立つて，あるいはリーチン グの実施中においても必要に応じて鉱体を破砕しておく ことが必要である。

鉱体の破砕法としては，(1) 核爆発を利用する破砕 法, (2)坑道式大発破を利用する破砕法, (3)ブロック・ ケービング法やサブレベル・ケービング法などを用いて 鉱体の下透しを行ない上部鉱石を崩落させて破挽する方 法，および (4) 水力による破砕法などが考えられる（第 2 図 $^{7}$ 参照)。

これらのらち，(1) の核爆発を利用寸る破砕法は，生 ずる破砕の規模や所要経費などから考えても膨大な鉱量 をもつ鉱床のみにしか応用できず，さらに核爆発にとも なら放射能污染や激しい地震動による被害などに対する 危惧を考慮すれば，わが国においては適用できる方法で はない。しかし，アメリカにおいては真剣に検討されて いるようで，実施計画も発表されているが8)，まだ実施 に移されてはいないようである。そのほか，核爆発と通 

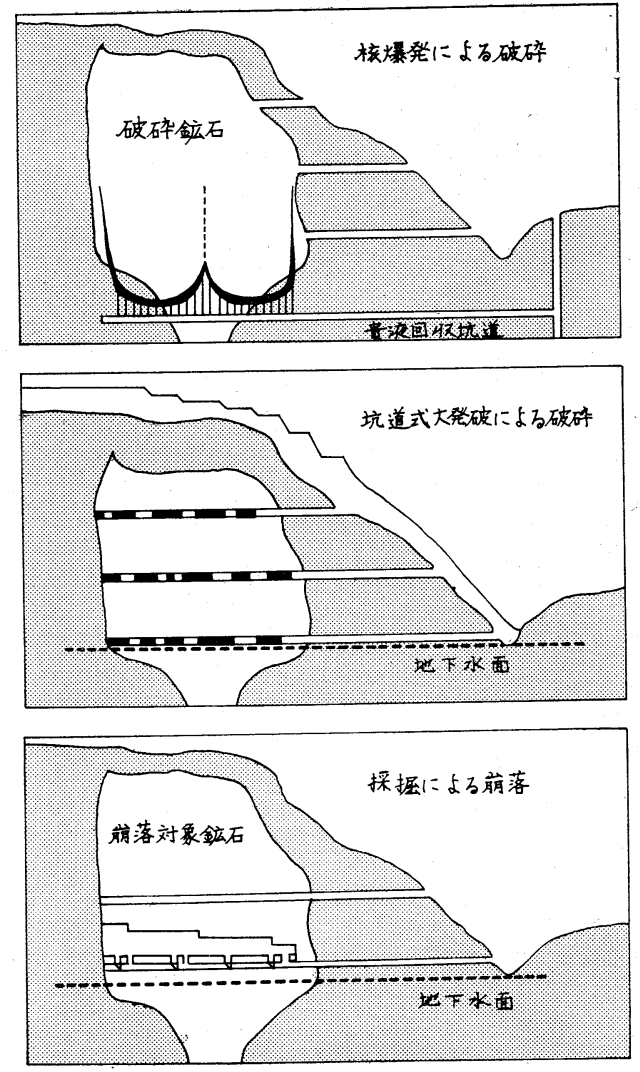

第 2 図，種々の方法による鈗床の破砕

(M. H. Ward 汇よる)

常の発破のそれぞれの方法によつて破砕された花崗岩に ついて，生じているきれつの程度とそれらのきれつへの 浸出液の浸透性を調べた報告9 も出されているが，それ によると，核爆発により破砕した花崗岩には微細なきれ つが数多く密汇生じて打り，浸出液もそれぞれのきれつ 先端近くまでよく浸透しているので, リーチングに対し ては好適であると述べている。

通常の爆薬を用いた発破により破研する方法は, 対象 鉱床の規模や状態に応じて適当な発破方法を選びうる利 点をもつている。比較的規模の大きい鉱床を発破のみで 破研しようとする場合には，(2) にあげた坑道式大発破 を利用する破砕法が適しているであ万うし，鈗床条件に よつては，すべての破砕を発破により行なうのではな く，たとえば（3）にあげたように，ブロック・ケービン グ法やサブレベル・ケービング法を用いて採掘する場合 と同様な方法で，発破により鉱体の下透しを行ない，上 部鈗石を崩落させて破砕する方法も有効と考元られる。 いずれにしても，発破による破砕法を用いる場合には， いかにすればリーチングに適した粒度と破砕範囲が得ら れるかが問題であつて，このような目的に適つた発破法 の開発が望まれている。

（4）にあげた水力による破砕法は，石油工学に沶いて 用いられている水攻法に準じた技術により鉱体内にきれ つを発生せしめるとともに，これらのきれつを拡大し発

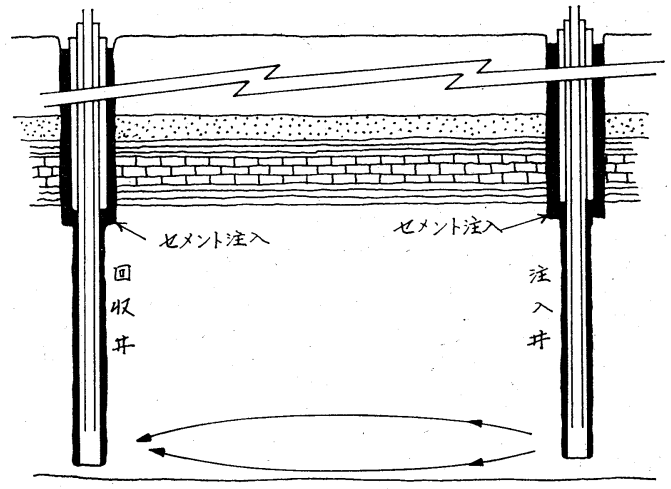

第3 図 水力による鉱床の破砕

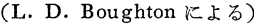

展させようとする方法である。すなわち，第 3 図 ${ }^{10}$ に示 すように，一方の井戸から高圧の液体を圧入し，孔底の 鉣床内でジェット流として噴出させて細かいきれつを発 生せしめ, さらにそれらを抬大させっつ延長して別に設 けられている他の井戸にまで達せしめる。この際，生じ たきれつが閉塞しないようにするためには，圧入する液 体に砂粒のような propping agent 学添加しておくこと

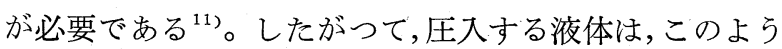
な propping agent が遊離しないできれつ内まで運ばれ うるように，適当な粘性をもつていなければならない。ま た,鉱床に対しきれつを発生せしめるためには, 鉱床の特 性に応じて圧入する液体は充分高い圧力をもつていなけ ればならないが，いったん生じたきれつを助長し発展せ しめるために必要な圧力は, 鉱床の梁度によつて定まる 静水圧よりもやや大きい程度で充分であるといわれてい る ${ }^{12)}$ 。さらに上記の方法で鉱床内にきれつを発生させ, リーチングに必要な充分な透水係数が得られれば，圧入 井を浸出液の注入井に，他方の井戸を回収井に利用する ことによつて直ちに in place leaching を行ならことが できることもこの破砕法の利点である。しかし，この方 法はどの上らな鉱床に対しても適用可能といらわけでは なく, 水力の上らな流体圧によつて破砕が可能な条件を もつ鉱体にのみ応用しらるものである。

つぎに，リーチング法に沶いては，注入された浸出液 が浸出反応を伴いつつ鉱床内を流動し，貴液となつて所 定の回收坑道または回収井に集水されてくることが必要 である。そのためには，浸出液が母岩中に，あるいは， 浸出対象区域外に逸水することは極力避けなければなら ない。母岩にきれつがなく，緻密で不透水層と考えられ るほど透水係数が小さい場合には好都合であるが，母岩 が鈗床と同程度のあるいはそれ以上の透水係数をもつ場 合には，母岩と鈗床との境界面に人工的な遮水壁を構筑 して抢くことが望ましい。未採掘の鉱床を破砕したり， 崩落させたのち in place leaching を行なら場合に，人 工的な遮水壁を構築することはむずかしいが，採掘跡の 
残鉱や低品位鈗を対象に in place leaching を実施する 場合には，すでに開さくされている坑道などを利用して グラウチィングを密に実施することより目的とする遮水 壁をつくることも可能であろう。

\section{$3 \cdot 3$ 浸出液による金属成分の溶解性}

リーチング法においては, 対象とする鉱石の種類に応 じて酸, 塩基, 塩類など各種の浸出液が用いられてい る。しかし, in place leaching のように, 浸出液を多 量に使用しなければならない反面，これらの浸出液ある いは貴液の制御が必ずしも容易でなく, 浸出および回収 の過程でかなりのロスを見込んでおかなければならない 場合には, 浸出液としてはたやすく入手できてしかも安 価であり，取り扱いも容易なものが要求される。一方， 先にも述べたように, in place leaching は今のところ 主として銅鉱执よびウラン鉱を対象として実施されてい るが, このような場合, 浸出液としての上記の条件を満 たすものとしてもつとも多く用いられているのが硫酸で ある。もつとも，たとえば黄鉄鉱を随汼している硫化銅 鉱床に対し硫酸を浸出液として in place leaching を行 なつた場合などには, 後述するように, 浸出の過程にお いては黄鉄鉱の酸化により硫酸第二鉄が生成していると 考えられるので, 鉱床内における実際の浸出反応には硫 酸第二鉄も重要な役割を果しているものと考えられる。

さて, リーチング法に拈いては, 浸出液に対する鉱石 中の金属成分の溶解性ということが，その成否を左右す るもつとも基本的な重要な問題である。一般的にいえ ば, この溶解性は, 鈗石の粒度, 使用する浸出液の種類 と濃度, 浸出液と鉱石（正しくは鉱石中の金属成分）と の接触時閒, 温度などの浸出条件によつて異なることは よく知られており，これらに関する研究成果も数多く発 表されている。その一例として第 1 表は, 硫酸および酸 性硫酸第二鉄溶液に対する純粋な各種銅鉱物の溶解性を

第 1 表 純粋な各種銅鉱物の溶解性 (G. D. Van Arsdale による)

\begin{tabular}{|c|c|c|c|c|}
\hline 鉱物名 & 粒 度 (mesh) & 溶 & $\begin{array}{c}\text { 浸出率, 浸出 } \\
(\%)\end{array}$ & 温度 \\
\hline 藍 銅 鉱 & $-100+200$ & $1 \sim 5 \% \quad \mathrm{H}_{2} \mathrm{SO}_{4}$ & 100,1 時間 & 窒温 \\
\hline 孔雀石 & $-100+200$ & $1 \sim 5 \% \quad \mathrm{H}_{2} \mathrm{SO}_{4}$ & 100,1 時間 & 室 温 \\
\hline 黒銅 鉱 & $-100+200$ & $1 \% \quad \mathrm{H}_{2} \mathrm{SO}_{4}$ & 98,1 時間 & 室温 \\
\hline 珪孔雀石 & $\begin{array}{c}-0.525 \text { in }+3 \text { mesh } \\
-10+28\end{array}$ & $\begin{array}{l}\mathrm{H}_{2} \mathrm{SO}_{4} \\
\mathrm{H}_{2} \mathrm{SO}_{4}\end{array}$ & $\begin{array}{r}100,30 \text { 時間 } \\
97,6 \text { 時間 }\end{array}$ & 室温 \\
\hline 翠銅鉱 & $\begin{array}{l}-10+28 \\
-10+28 \\
-10+28 \\
\end{array}$ & $\begin{array}{ll}1 \% & \mathrm{H}_{2} \mathrm{SO}_{4} \\
2 \% & \mathrm{H}_{2} \mathrm{SO}_{4} \\
5 \% & \mathrm{H}_{2} \mathrm{SO}_{4} \\
\end{array}$ & $\begin{array}{r}79,60 \text { 日 } \\
98,60 \text { 日 } \\
100,37 \text { 日 } \\
\end{array}$ & 室温 \\
\hline 赤 銅 鉱 & $\begin{array}{c}-10+28 \\
-100+200 \\
\end{array}$ & $\begin{array}{l}\text { 酸性 } \mathrm{Fe}_{2}\left(\mathrm{SO}_{4}\right)_{3} \\
\text { 酸性 } \mathrm{Fe}_{2}\left(\mathrm{SO}_{4}\right)_{3}\end{array}$ & $\begin{array}{cc}99, & 3 \text { 日 } \\
100, & 1 \text { 時間 }\end{array}$ & 室温 \\
\hline 輝 銅 鉱 & $\begin{array}{l}-100+200 \\
-100+200 \\
-100+200 \\
-100+200\end{array}$ & $\begin{array}{l}\text { 酸性 } \mathrm{Fe}_{2}\left(\mathrm{SO}_{4}\right)_{3} \\
\text { 酸性 } \mathrm{Fe}_{2}\left(\mathrm{SO}_{4}\right)_{3} \\
\text { 酸性 } \mathrm{Fe}_{2}\left(\mathrm{SO}_{4}\right)_{3} \\
\text { 酸性 } \mathrm{Fe}_{2}\left(\mathrm{SO}_{4}\right)_{3}\end{array}$ & $\begin{array}{c}50,24 \text { 時間 } \\
100,21 \text { 日 } \\
50,8 \text { 日 } \\
95,8 \text { 日 }\end{array}$ & $\begin{array}{l}35^{\circ} \mathrm{C} \\
35^{\circ} \mathrm{C} \\
23^{\circ} \mathrm{C} \\
50^{\circ} \mathrm{C}\end{array}$ \\
\hline 斑 銅 鉱 & $\begin{array}{l}-100+200 \\
-100+200 \\
-100+200 \\
\end{array}$ & $\begin{array}{l}\text { 酸性 } \mathrm{Fe}_{2}\left(\mathrm{SO}_{4}\right)_{3} \\
\text { 酸性 } \mathrm{Fe}_{2}\left(\mathrm{SO}_{4}\right)_{3} \\
\text { 酸性 } \mathrm{Fe}_{2}\left(\mathrm{SO}_{4}\right)_{3}\end{array}$ & $\begin{array}{l}95,14 \text { 日 } \\
45, \quad 5 \text { 日 } \\
85, \quad 3 \text { 日 }\end{array}$ & $\begin{array}{l}\text { 室 温 } \\
23^{\circ} \mathrm{C} \\
50{ }^{\circ} \mathrm{C}\end{array}$ \\
\hline 銅藍 & $\begin{array}{l}-100+200 \\
-100+200 \\
\end{array}$ & $\begin{array}{l}\text { 酸性 } \mathrm{Fe}_{2}\left(\mathrm{SO}_{4}\right)_{3} \\
\text { 酸性 } \mathrm{Fe}_{2}\left(\mathrm{SO}_{4}\right)_{3}\end{array}$ & $\begin{array}{ll}35,11 日 \\
70, & 13 \text { 日 } \\
\end{array}$ & $\begin{array}{l}35^{\circ} \mathrm{C} \\
50^{\circ} \mathrm{C} \\
\end{array}$ \\
\hline 黄 銅 鉱 & $\begin{array}{l}-100+200 \\
-350 \\
-350 \\
\end{array}$ & $\begin{array}{l}\text { 酸性 } \mathrm{Fe}_{2}\left(\mathrm{SO}_{4}\right)_{3} \\
\text { 酸性 } \mathrm{Fe}_{2}\left(\mathrm{SO}_{4}\right)_{3} \\
\text { 酸性 } \mathrm{Fe}_{2}\left(\mathrm{SO}_{4}\right)_{3}\end{array}$ & \begin{tabular}{|r|}
2,43 日 \\
$38 \sim 39,57$ 日 \\
44,14 日
\end{tabular} & $\begin{array}{l}\text { 室 温 } \\
\text { 笽 } \\
500^{\circ} \mathrm{C}\end{array}$ \\
\hline
\end{tabular}

示したものである ${ }^{13)}$ 。

しかし，天然に産する鉱物は必ずしも純粋なものでは なく，種々の不純物を含んでいる場合が多い。このよう な鉱物では, 浸出液に対する含有金属成分の溶解性も個 々の鉱物の特性に影響されるために, その溶解性につい ては，同一種の鉱物についてすでに知られている従来の 資料をもとにして判断することはむずかしい。したがつ て，実施に先立つて行なら基礎実験において，対象とす る個々の鉱物について各種の浸出液に対する金属成分の 溶解性を求めておくことが必要である。

\section{$3 \cdot 4$ 浸出機構}

$3 \cdot 4 \cdot 1$ 溶媒 (浸出液) に上る浸出溶媒による浸 出の機構については湿式治金の分野ですでに明らかにさ れてきている。たとえば, in place leachingにもつとも 関係の深い数種の銅鉣物を硫酸あるいは硫酸第二鉄を用 いて浸出するときの反応はつぎに示すとおりである ${ }^{14)}$ 。 藍銅鉙 :

$$
\begin{array}{r}
\mathrm{Cu}_{3}(\mathrm{OH})_{2} \cdot\left(\mathrm{CO}_{3}\right)_{2}+3 \mathrm{H}_{2} \mathrm{SO}_{4}=3 \mathrm{CuSO}_{4} \\
+2 \mathrm{CO}_{2}+4 \mathrm{H}_{2} \mathrm{O} \ldots \ldots \ldots \ldots \ldots \ldots \ldots \ldots \ldots \ldots \ldots \ldots \ldots \ldots \ldots \ldots \ldots \ldots \ldots
\end{array}
$$

孔雀石:

$$
\begin{array}{r}
\mathrm{Cu}_{2}(\mathrm{OH})_{2} \cdot \mathrm{CO}_{3}+2 \mathrm{H}_{2} \mathrm{SO}_{4}=2 \mathrm{CuSO}_{4} \\
\quad+\mathrm{CO}_{2}+3 \mathrm{H}_{2} \mathrm{O} \ldots \ldots \ldots \ldots \ldots \ldots \ldots \ldots \ldots \ldots \ldots \ldots \ldots \ldots \ldots \ldots
\end{array}
$$

珪孔雀石 :

$$
\mathrm{CuSiO}_{3} \cdot 2 \mathrm{H}_{2} \mathrm{O}+\mathrm{H}_{2} \mathrm{SO}_{4}=\mathrm{CuSO}_{4}
$$$$
+\mathrm{SiO}_{2}+3 \mathrm{H}_{2} \mathrm{O}
$$

赤銅鉣 :

$$
\begin{aligned}
& \mathrm{Cu}_{2} \mathrm{O}+\mathrm{H}_{2} \mathrm{SO}_{4}=\mathrm{CuSO}_{4}+\mathrm{Cu}+\mathrm{H}_{2} \mathrm{O} \\
& \mathrm{Cu}+\mathrm{Fe}_{2}\left(\mathrm{SO}_{4}\right)_{3}=\mathrm{CuSO}_{4}+2 \mathrm{FeSO}_{4} \cdots \\
& \mathrm{Cu}_{2} \mathrm{O}+\mathrm{H}_{2} \mathrm{SO}_{4}+\mathrm{Fe}_{2}\left(\mathrm{SO}_{4}\right)_{3}=2 \mathrm{CuSO}_{4} \\
& \quad+\mathrm{H}_{2} \mathrm{O}+2 \mathrm{FeSO}_{4} \ldots \ldots \ldots \ldots \ldots \ldots \ldots \ldots \ldots \ldots \ldots \ldots \ldots \ldots \ldots \ldots
\end{aligned}
$$

輝銅鉣 :

$$
\begin{array}{r}
\mathrm{Cu}_{2} \mathrm{~S}+\mathrm{Fe}_{2}\left(\mathrm{SO}_{4}\right)_{3}=\mathrm{CuS} \\
+\mathrm{CuSO}_{4}+2 \mathrm{FeSO}_{4} \ldots
\end{array}
$$

$$
\mathrm{CuS}+\mathrm{Fe}_{2}\left(\mathrm{SO}_{4}\right)_{3}=\mathrm{CuSO}_{4}
$$$$
+2 \mathrm{FeSO}_{4}+\mathrm{S}
$$

$\mathrm{Cu}_{2} \mathrm{~S}+2 \mathrm{Fe}_{2}\left(\mathrm{SO}_{4}\right)_{3}=2 \mathrm{CuSO}_{4}$

$$
+4 \mathrm{FeSO}_{4}+\mathrm{S}
$$

銅 藍:

$\mathrm{CuS}+\mathrm{Fe}_{2}\left(\mathrm{SO}_{4}\right)_{3}=\mathrm{CuSO}_{4}$

$$
+2 \mathrm{FeSO}_{4}+\mathrm{S}
$$

黄銅鉱

$\mathrm{CuFeS}_{2}+2 \mathrm{Fe}_{2}\left(\mathrm{SO}_{4}\right)_{3}+2 \mathrm{H}_{2} \mathrm{O}+3 \mathrm{O}_{2}$

$$
=\mathrm{CuSO}_{4}+5 \mathrm{FeSO}_{4}+2 \mathrm{H}_{2} \mathrm{SO}_{4}
$$

\section{$3 \cdot 4 \cdot 2$ 浸出反応における細菌の役割} 20 年ほど前に, 鉱山の坑内や坑内水中に特殊の細 菌が棲息していて，これらの細菌が金属鈗物や鉱 石からの有用金属の溶出に対して効果的な作用を もつことが発見されたことがきつかけとなつてバ 
クテリア・リーチングに関する関心が高まり，各方面で 研究が行なわれていることは周知の事柄である。バクテ リア・リーチングについては，すでに他誌に総説として とりまとめたものを寄稿し揭載されているので ${ }^{15)}$, 詳し くはそれらを参照してもららこととし，ここでは細菌に よる浸出機構のみについてふれておくことにする。

金属鉣物や鉣石からの有用金属の浸出に際して細菌が どのような役割を果しているのかといういわゆる浸出の 機構についてはなお明らかでない点が多い。このことに 関して今日までに提示されている考え方を整理してみる と，おおよそつぎの三つに分けることができる。すなお ち，その一つは，細菌そのものが直接鉱物や鉱石中の有 用金属に作用して浸出作用をなすのではなく，有用金属 の浸出は純化学的な反応によつて行なわれるのである が，この浸出に必要な溶液条件を整える際に細菌が触媒 的なきわめて有効な働きをしているという説（間接的接 触機構）である。これに対してもら一つの説は，鉱物や 鉣石からの有用金属の浸出が単に純化学的な反応のみに よつて行なわれるのではなくて, 細菌の営む生化学的な 反応がなんらかの形で浸出作用に大きく関与していると 考えるものである（直接的接触機構）。、以下これらに関 し簡単に説明を加えておこう。

（1）間接的接触機構 T. thiooxidans や T. concretivorus のようなイオウ酸化細菌は元素イオウを酸化 する機能をもつているから，これらが棲息している溶液 中には硫酸が生成される。また，F.ferrooxidans や T. ferrooxidans などの鉄酸化細菌はいずれも硫酸第一 鉄を酸化して硫酸第二鉄を生成する機能をもつているか ら，これらの細菌が棲息している溶液は硫酸第二鉄に富 むことになる。そこでこの説では，バクテリア・リーチ ングにおいても，なんらかの作用によつて生成された硫 酸や硫酸第二鉄が直接の溶媒となつて化学的な反応を行 ない有用金属が浸出されるのであるが，自然酸化による 硫酸や硫酸第二鉄の生成速度はきわめて緩慢であるのに 対し，それぞれの細菌が関与するようになるとその速度 は触媒的な規模で加速され，これが効果的な浸出を行な う根本要因をなしていると考えるものである。一例とし て，鉄酸化細菌による硫化鉣物や鉣石からの鉄および銅 の浸出について述べてみよう ${ }^{16)}$ 。多くの金属硫化鉱物よ りなる鉱石は必ずといつてよいほど黄鉄鉱を含んでいる が，この黄鉄鉣は酸素と水との存在のもとで徐々に酸化 され，硫酸第一鉄と硫酸を生成する。

$$
2 \mathrm{FeS}_{2}+7 \mathrm{O}_{2}+2 \mathrm{H}_{2} \mathrm{O} \rightarrow 2 \mathrm{FeSO}_{4}+2 \mathrm{H}_{2} \mathrm{SO}_{4}
$$

鉄酸化細菌は酸素と硫酸の存在のもとで硫酸第一鉄を 酸化するが，この反応は一種の触媒的な速さで行なわ れ，急速に硫酸第二鉄を生成する。

$4 \mathrm{FeSO}_{4}+2 \mathrm{H}_{2} \mathrm{SO}_{4}+\mathrm{O}_{2}$ ベクテリア $2 \mathrm{Fe}_{2}\left(\mathrm{SO}_{4}\right)_{3}$

$$
+2 \mathrm{H}_{2} \mathrm{O}
$$

このようにして生成された硫酸第二鉄は金属硫化鉣物 に作用して目的とする金属を金属硫酸塩の形で浸出す る。たとえば，輝銅鉱に作用した場合には，(15)式に示 す反応が行なわれ，硫酸銅，硫酸第一鉄，イオウを生成 する。

$$
\begin{array}{r}
\mathrm{Cu}_{2} \mathrm{~S}+2 \mathrm{Fe}_{2}\left(\mathrm{SO}_{4}\right)_{3} \rightarrow 2 \mathrm{CuSO}_{4} \\
+4 \mathrm{FeSO}_{4}+\mathrm{S} \quad \cdots \cdots \cdots \ldots \ldots \ldots \ldots \ldots
\end{array}
$$

また，黄鉄鉱は硫酸第二鉄と作用して硫酸第一鉄と硫 酸を生成する。

$$
\mathrm{FeS}_{2}+7 \mathrm{Fe}_{2}\left(\mathrm{SO}_{4}\right)_{3}+8 \mathrm{H}_{2} \mathrm{O} \rightarrow 15 \mathrm{FeSO}_{4}
$$$$
+8 \mathrm{H}_{2} \mathrm{SO}_{4}
$$

(15), (16) 式の反応で生成された硫酸第一鉄は鉄酸化 細菌によつてふたたび酸化され，硫酸第二鉄となる。し たがつて，このような反応が溶液中でサイクル的に繰り 返されつつ浸出反応が進行してゅくわけである。もしこ の溶液中にイオウ酸化細菌が存在すれば，(15)式の反応 で生成されたイオウはこれらの細菌によつて酸化され， (17)式の反応によつて硫酸を生成し，この硫酸も溶媒と して有効な浸出作用を行なうことになる。

$2 \mathrm{~S}+3 \mathrm{O}_{2}+2 \mathrm{H}_{2} \mathrm{O}$ パクテリー $2 \mathrm{H}_{2} \mathrm{SO}_{4}$

（2）直接的接触機構 バクテリア・リーチングに おいては, 細菌が直接イオウや金属に作用して浸出を促 進したり，また細菌の営む複雑な反応がなんらかの形で 浸出に関与し，効果的に作用しているといら考え方もか なり行なわれている。ここに，その一，二の例を紹介し ておく。

Silverman は $F$. ferrooxidans による黄鉄鉱の酸化 機構についてつぎのような方法で検討した ${ }^{17)}$ 。すおわ ち，試料として用いた黄鉄鉱には酸可溶性の鉄が含まれ ているため，まず， $2 \mathrm{~N}$ 塩酸を用いて蒸気浴上で 30 分間 抽出することによつて酸可溶性鉄を除去したものと，こ のような処理を施さないものとの 2 者について， F. ferrooxidans を作用させたときの酸化速度を調べてみ た。初発 $\mathrm{pH}$ は硫酸で調節して 3.5 に保つた。その結

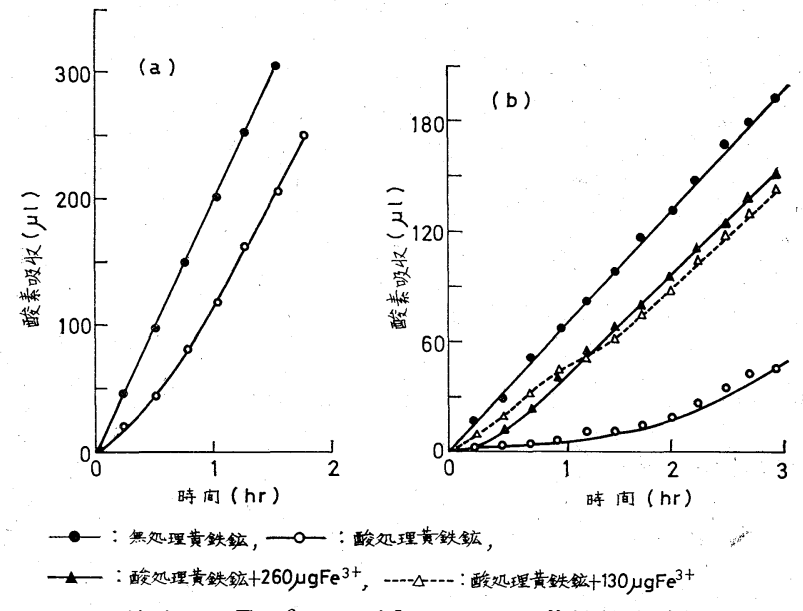

第 4 図 $F$. ferrooxidans による黄鉄鉱の酸化 (M. P. Silverman 飞よる) 
果，第 4 図(a)に示したように, 酸素吸収は無処理の黄 鉄鉱の場合には直線的に進むが，酸処理した黄鉄鉱の場 合には直線にならないことがわかつた。そこで, 酸処理 した黄鉄鉱に 130 260 $\mu \mathrm{g}$ の硫酸第二鉄を添加してみた ところ, 第 4 図 (b)に示すように, 酸化力は無処理の場 合のそれのほぼ $2 / 3$ に回復し, 酸素吸収もほぼ直線に近 くなつた。このような実験結果に対してかれはつぎのよ うに推論している。すなわち，黄鉄鉣中に存在している 酸可溶性の鉄は硫酸第一鉄が主体であるから，無処理の 黄鉄鉣の場合には，まずこの硫酸第一鉄が F. ferrooxidans によつて硫酸第二鉄に酸化され，ついで生成した 硫酸第二鉄は前項の (16)式の反応によつて黄鉄鉱を酸化 するとともにみずからは硫酸第一鉄に還元される。この 硫酸第一鉄はふたたび細菌によつて酸化され硫酸第二鉄 になる。このようにして反応が継続的に進むものと考え られる。したがつて，無処理の黄鉄鉱の場合に直線的な 酸素吸収を示した反応は, 間接的接触機構による酸化を 意味しているものと考えられる。酸処理を施した黄鉄鉱 の場合でも，硫酸第二鉄を添加すれば酸化力を回復し， 酸素吸収がほぼ直線に近くなつたことはこれを裏書きす るものといえる。これに対して，酸処理を施した黄鉄鉱 の場合には，上記のような硫酸第二鉄による無機的な酸 化は起こりえないと考えられるから，この場合曲線的な 酸素吸収を示した反応は，細菌が黄鉄鉱に対してなんら かの直接的な作用を与えたために生じた酸化であると考 えることができると述べている。しかし，直接的接触機 構についてはそれ以上の媣い検討がなされていない。

つぎに筆者らは，すでにイオウ酸化細菌と鉄酸化細菌 の存在が確認されているわが国のK鉣山の坑内各所から 多数の坑内水試料を採取し，それらの試料水について 7 日間の培養を行なつて得られた細菌数をもとにして, 坑内の環境条件と細菌の分布状況, および試料水中の溶 存成分との関係を調べてみた ${ }^{18)}$ 。細菌数はトーマの計測

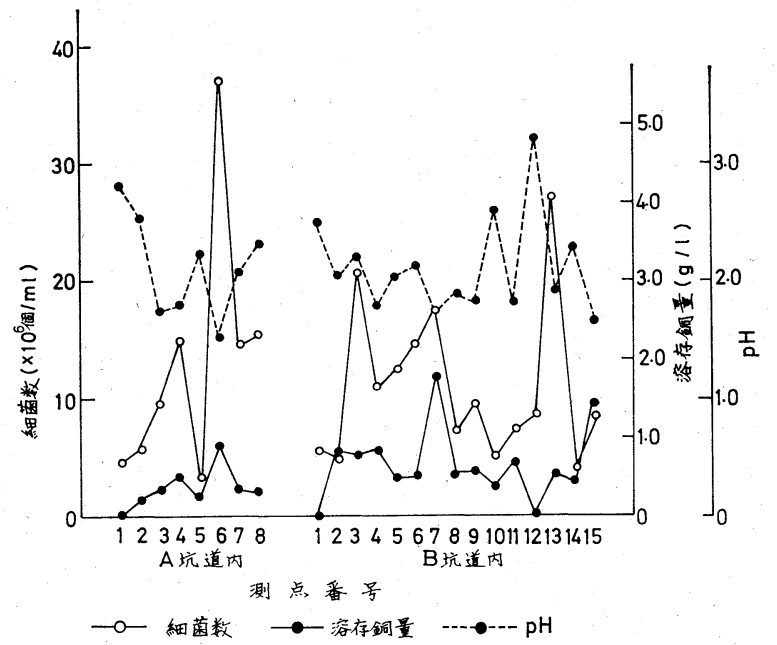

第 5 図 K鉱山の坑内水中の細菌数と溶存銅量, $\mathrm{pH}$ との関倸
器によつて求めたので概略值にすぎないが, 得られた結 果のらち, 細菌数と試料水中の溶存銅量および $\mathrm{pH}$ 值と の関係を示すと第 5 図のとおりである。図に明らかなよ らに, 細菌数と溶存銅量との間にほほぼ比例的な対応 が，また細菌数および溶存銅量と $\mathrm{pH}$ 值との間にはほぼ 逆比例的な対応が認められるが, これは非常に興味深い ことである。このことと, さらに坑内においては, 母岩 部よりも鉱体中あるいは鉱体周辺部において細菌の生育 がより顕著であつたことを考え合わせると，これらは直 接的接触機構を支持する一つの現象であるとも考えうる わけである。

さらに，硫酸にはまつたく溶けない二酸化マンガンが T. thiooxidans を用いたバクテリア・リーチングでは 容易に溶出することは, 今井らの研究 ${ }^{19}$ で明らかにされ でるが,その機構について今井ら ${ }^{20)}$ は, T. thiooxidans がイオウを酸化して硫酸を生成する際, 酸化の中間生成 物として亜硫酸が生成され, その亜硫酸が 4 価のマンガ ンを 2 価のマンガンに還元する。4 価のマンガンは硫酸 には不溶であるが，2価のマンガンは硫酸に容易に溶け るので, 結局は二酸化マンガンからマンガンが溶出する ようになると明快な説明を与えている。このように，バ クテリア・リーチングにおいては, 細菌の営む生化学的 な反応により金属成分を溶けやすい状態に変えて浸出効 果を高めている可能性も充分考えられるわけである。

そのほか, Schaeffer ら ${ }^{21}$ は，T. thiooxidans の作 用をらけたイオウ結晶には細菌の侵蝕作用のあとが歷然 とみられることを写真撮影によつて示し, このことから この細菌はイオウを直接侵し酸化できるのではないかと 述べている。なお, 直接的接触機構については, Le Roux $^{22)}$ やBeck $ら^{23)}$ の推論も発表されていることを付 記して拉く。

\section{$3 \cdot 5$ 貴液よりの金属成分の回収}

浸出によつて生じた貴液中には，目的とする金属成分 のほかに，種々の不純物が混入している。このような貴 液から目的とする金属成分を回収する方法は，すでに湿 式治金の分野においてそれぞれの金属成分の種類に応 じて有効な方法が確立されている。一方，わが国におい ては, in place leaching は主として銅鉣床に対する応 用に関心がもたれているので，ここでは紙数の関係上， 貴液からの銅の回収法としてもつとも多く一般的に用い られているセメンテーション法のみについて簡単にふれ ておくことにする。なお, 貴液からの銅の回収法として は，セメンテーション法以外に，硫化水素により硫化銅 として沈殿させて回収する方法, 陽イオン交換液による 溶媒抽出法が一部の鉱山で用いられており，また，イオ ン浮選法によつても銅の回収が可能であることが指摘さ

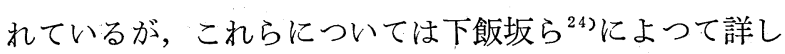
く紹介されているので, 参照されたい。 
さて，セメンテーション法は，銅イオンを含む溶液中 に金属鉄を投入することにより，銅と鉄のイオン化傾向 の差を利用して金属銅を沈殿せしめ，これを処理して回 収する方法である。この際の反応は(18)式によって示さ れるが，一般に貴液の中には硫酸や硫酸第二鉄が含まれ ているから，(18)式の反応以外に，(19) （21)式の反応 も起こり ${ }^{25)}$ ，そのため余分の鉄が消費されることにな る。

$$
\begin{aligned}
& \mathrm{Cu}^{2+}+\mathrm{Fe} \rightarrow \mathrm{Cu}+\mathrm{Fe}^{2+} \ldots . \\
& \mathrm{Fe}+\mathrm{Fe}_{2}\left(\mathrm{SO}_{4}\right)_{3} \rightarrow 3 \mathrm{FeSO}_{4} \\
& \mathrm{Fe}+\mathrm{H}_{2} \mathrm{SO}_{4} \rightarrow \mathrm{FeSO}_{4}+\mathrm{H}_{2} \\
& \mathrm{Cu}+2 \mathrm{Fe}^{3+} \rightarrow \mathrm{Cu}^{2+}+2 \mathrm{Fe}^{2+}
\end{aligned}
$$

したがって，操業にあたつては，(19)〜(21)式の反応を できるだけ抑制し，(18)式の反応を促進するような工夫 がなされなければならない。(18)式の反応速度は(19)

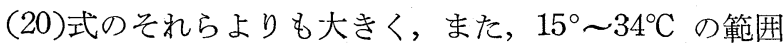
では, 温度の上昇とともに, 反応も促進されるといわれ ている。さらに，(18)式の反応は，銅イオンを払散して 金属鉄表面への接触状態をよくするとともに，金属鉄表 面に付着沈殿した金属銅をできるだけ速や办にとり除 き，つねに新鮮な鉄表面が溶液に接触するようにするこ とによって促進させることができる。そのために，ふつ らは沈殿銅採取用の木樋あるいは採取槽の下部から空気 を吹込んだり, 回転ドラム型の採取槽を用いたりして, 主として䚓拌効果によって反応を促進する方法がとられ ている。Kennecott Copper Corporation で開発された Cone precipitator は, その 1 種 ${ }^{26}$ では, コーンの内壁 にとりつけられたパイプ先端のノズルから，くず鉄が充 填されているコーン内に渦流状に貴液を注入することに より鉄表面からの沈殿銅の除去と反応の促進をはかつて おり,他の 1 種 ${ }^{27}$ では,水素ガス発生量に応じて自動的な 沈殿銅のとり出しとくず鉄の補給が行なえるようになつ て抢り，これらのいずれを用いても，最小限の鉄消費量 で高い銅実収率が得られるよう工夫されている。また， これらの装置では, くず鉄の装入, 沈殿銅および未反応 のくず鉄のとり出しなど従来主として人力に頼っていた 作業をも自動化されており，大規模操業を効率上く行な いうるようになっている。

\section{4. in place leaching $の$ 実施例}

\section{$4 \cdot 1$ 小坂鉱山における実施例 ${ }^{28)}$}

小坂鉣山元山釷床は，第 3 紀層の凝灰角砂岩および流 紋岩を母岩とする塊状の黒鉱鉱床であるが，現在 in place leaching の対象となつているのは低品位珪鉱であ つて，黄鉄鈗を主とし，少量の輝銅鉱，銅藍，黄銅鉱を 含む鉣染状または網状の珪化釷体である。ここで害施さ れている in place leaching の操業系統は第 6 図に示す とおりである。すなわち，露天掘跡および上部坑道から

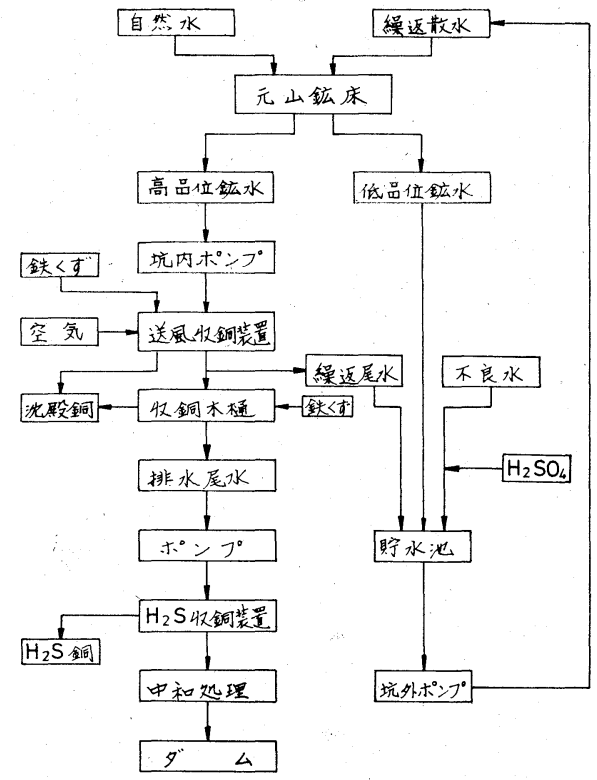

第6 図 小坂鉱山における沈殿銅採取系統図 （阿部による）

浸出液を撒水してき裂帯を流下させ，鉱体中の銅分を浸 出させる。貴液は坑内各所湧出するが，含銅品位は大 幅に変動しているので，坑内に扔いて低品位鈗水と高品 位鉱水とに仕分けられつつ立坑底に集められる。高品位 鈗水は沈殿銅採取釷水として立坑底に設置したポンプで 揚水し，坑外の送風収銅装置に送つてセメンテーショシ 法により沈殿銅を採取する。沈殿銅採取後の大部分の尾 水は，貯水池において固形物を除き清澄となつた低品位 鉱水と合わせて上部坑道に揚水し，浸出液として繰り返 し使用されている。ほぼ自然涌水分に見合ら一部の收銅 尾水は，硫化水素ガスを通じて残存している銅分を硫化 銅として回収したのち中和処理を施し，ダムに放流して いる。沈殿銅の実收率は約 $95 \%$ ，鉄くず消費量は銅 $1 \mathrm{t}$ に対し $2.6 \sim 2.8 \mathrm{t}$ ，沈殿銅の銅品位は $87 \%$ 前後である。

なお，ここでは，浸出条件を整えるために，月間 100 $\mathrm{m}$ 前後の坑道掘進, $600 \mathrm{~m}$ 程度の長孔ボーリングのほか に, 装薬量 $1 \mathrm{t}$ 前後の坑道式大発破を月 $1 \sim 2$ 回程度実 施しているが，さらに楼息が確認されている鉄酸化細菌 およびイオウ酸化細菌の自然増殖を促進するよう心掛け るとともに，多年にわたる操業経験と現場研究の結果か ら,

（1）鉱水撒水量を増加させてもかえつて貴液の品位 が低下して増収にはならない。むしろ撒水個所を増や し，1 個所あたりの撒水量を少なくした方が貴液の品位 が上昇し，生産量は増加する。

（2）撒水鉱水中の $\mathrm{Fe}^{3+} / \mathrm{Fe}^{2+}$ が小さくなるにつれ て貴液品位が上昇し，生産量が増す。元山坑の場 合に は, $\mathrm{Fe}^{3+} / \mathrm{Fe}^{2+}$ が 0.2 のときが最適である。このよう に，撒水鉱水中の鉄イオン濃度比を最適条件に保つため には，高品位鉣水子低品位鉱水の分離による鉱水の選択 
管理を実施することが必要である。

などの操業上重要なポイントを㨔み，それにもとづく 対策を実施することにより操業成績を向上させているこ とは注目に值する。

\subsection{Miami 鉱山における実施例 ${ }^{29) 30)}$}

アメリカのアリゾナ州にある. Miami 鉱山の鉣床は片 岩中に胚胎している鉱層で，主鈗物は輝銅鉙であるが， 黄銅鉱, 斑銅鉱, 銅藍, 孔雀石, 藍銅鉱なども随汼して いる。この鉱床は1959年まで主としてブロック・ケービ ング法により採掘されていたが，現在は採掘時の残鉱お よび未採掘の低品位鉣を対象にして in place leaching が行なわれている。すなわち，第7 図にその概念図 を示したように, 旧採掘跡の $305 \mathrm{~m}$ 坑道を集水坑道にし て，そこに貴液の溜池をつくり，そこから坑外の収銅装 置に揚水し，セメンテーション法により25t/日の沈殿銅 を回収している。収銅後の尾水の $\mathrm{pH}$ は 4.0 であるが, これに硫酸を添加して pH 2.8 にして山頂の溜池に送 り，そこでふたたび硫酸を添加して $\mathrm{pH} 1.4$ に調整した のち，浸出液として撒水している。鉄くずおよび硫酸の 消費量は，銅 $1 \mathrm{t}$ につきそれぞれ $1.3 \mathrm{t}$ および $2.4 \mathrm{t}$ ，ま た，沈殿銅の実収率は99\%，銅品位は約79\%である。

この鉱山では，リーチングの対象面積はほぼ $0.46 \mathrm{~km}^{2}$ で，山頂で撒水された浸出液がほぼ $180 \mathrm{~m}$ あまりの鉣体 中を流下して集水されるまでに $3 \sim 4$ 週間を要するとい われている。また，坑内には鉄酸化細菌およびイオウ酸 化細菌が棲息しており，これらの細菌が浸出を促進して いることが認められているが，一方，浸出液の流路が鉄 の沈殿により閉塞されないようにするために, 浸出液の $\mathrm{pH}$ 調整に特別の注意が払われている。さらに，一定の 浸出期間ののちに休止期間を設け，その間に鉱体の酸化 を促進させる方法は in place leaching においては有効 といわれているが，この鉱山でも，一定の浸出期間後つ

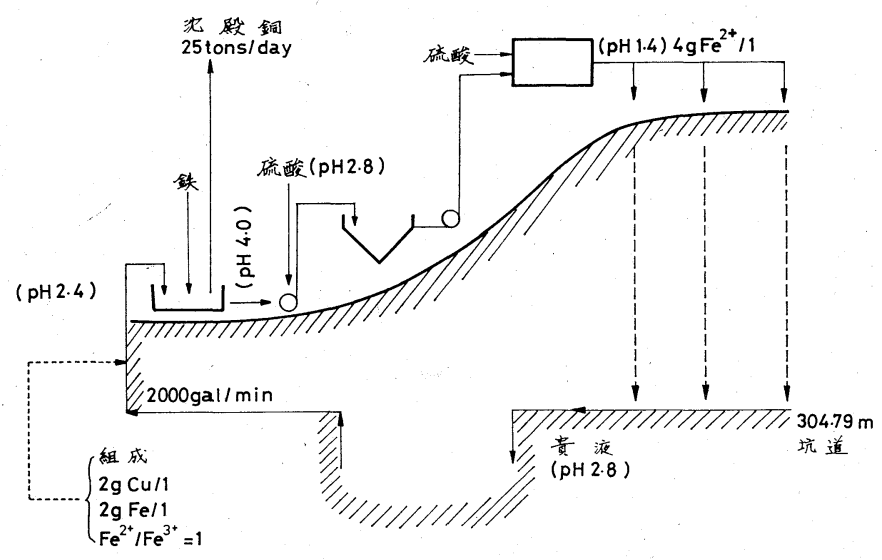

第7図 Miami 鉱山における in place leaching 実施概念図 (A. W. Fletcher 飞よる)
ぎの浸出作業を開始するまでにほぼ 3 カ月の休止期間を おくことにより好結果を得ている。

\section{5. 結訔}

以上に, in place leaching について, その特徵, 基 礎となる技術，および実施例について概説した。かなり 膨大な内容を限られた紙面に要約しなければならなかつ たため，説明が不充分であつたり，また，子れなければ ならない問題にふれ得なかつたなど不満足な点は多い が，お許しいただきたい。

ここでこの稿の結びとして, 最後に in place leaching の問題点について述べておきたい。

in place leaching は, 自然の状態で未採掘のまま存 在するか, あるいは採掘作業などによりある程度乱され た状態になつているかの別はあるにしても，とにかく鉱 床に対してリーチングの技術を直接応用しょうとする方 法である。したがつて，その成否は，鉣床中に含まれて いる鉣物の溶媒による浸出性と, 鉱床そのものをいかに して浸出に適する条件に整えていくかという二つの点に かかつているといつても過言ではない。自然に生成され ている鈗床は，たとえ同一の鉱種であつても，個々の鉱 床のもつ特性は千差万別であつて決して一定していな い。したがつて，溶媒に対する浸出性においても，一つ 一つの鉱床がそれぞれ別個の特性を示するのであるか ら，鉱床中における浸出条件を整える際にも，個々の鉱 床の浸出性を充分考慮に入れ，可能なかぎり最適条件が 得られるように配慮されなければならない。これらの点 が in place leachingのむずかしさでもあり，また，興 味のある点でもある。

\section{参考 文 献}

1) R. S. Shoemaker, R. M. Darrah: Min. Eng., Dec., 1968, p. 68

2) M. H. Ward: Min. Cong. Jour., 59, No. 1, 1973, pp. 21 27

3) 今泉常正: 昭和 47 年度日本鉱業会秋季大会分科研究会資料 P-1, pp. 1 4

4) たとえば, 酒井軍治郎 : 地下水学, 朝倉書店, 昭和40年, pp. 301 306

5) G. G. Hunken: SME, AIME, Preprint 71-As-88, Feb., 1971

6) R. H. Jacobson, Jr., C. R. Mckee, R. J. Roman, J.A. Brierley, R. B. Bhappu: Joint Meeting, MMIJ-AIME, 1972, Tokyo, Print N o. TIV a 3, May, 1972

7) M. H. Ward: ibid. 2)

8) Eng. and Min. Jour., 168, No. 11, 1967, pp. 116 122

9) D. D. Rabb: SME, AIME, Preprint 69-As-4, Feb., 1969

10) L. D. Boughton: SME, AIME, Preprint 71-As-36, Feb., 1971

11) J. B. Clark: Petroleum Trans., AIME, Jan., 1949, pp. 1 8

12) G. Griswold: SME, AIME, Preprint 69-As-74, Feb., 1969

13) G. D. Van Arsdale: Hydrometallurgy; of Base Metals, McGraw-Hill Book Co. Inc., 1953, p. 14

14) G. D. Van Arsdale: ibid. 13)

15）伊藤一郎：醴䤉工学雑誌，46，No. 4，1968，pp. 325 335，工業 化学雑誌, 72, No. 2, 1969, pp. 437 443, 化学, 24, No. 9, 1969, pp. 818 $\sim 825$

16) J. A. Sutton, J. D. Corrick: Min. Eng., 15, 1963, p. 37

17) M. P. Silverman: Jour. of Bacteriology, 94, 1967, p. 1046

18）伊藤一郎：バクテリヤ・リーチング研究会第 6 回研究討論会講演要 旨集, 1969

19）田野達男 -今井和民：日本農芸化学会誌，37，1963，p. 576

20) 今井和民・奥積昌世・片桐英郎：酵素化学シンポジムム, 第 17 集, 1962, p. 132

21) W. I. Schaeffer, P. E. Holbert, W. W. Umbreit: Jour. of 
Bacteriology, 85, 1963, p. 137

22) N. W. Le Roux: Microbial Aspects of Metallurgy, Medical and Technical Publishing Co. Ltd., Aylesbury

23) J. V. Beck, D. G. Brown: Jour. of Bacteriology, 96, 1968, pp. 1143 1434

24）下飯坂潤三・松岡功：昭和 47 年度日本釷業会秋季大会分科研究会資料 P-2, pp. 1 6

25) A. W. Fletcher: Microbial Aspects of Metallurgy, Medical, and
Technical Publishing Co. Ltd., Aylesbury

26) H. R. Spedden, E. E. Malouf, J. D. Prater: Min. Eng., 19, 1966, p. 57

27) A. E. Back: Trans., AIME, 238, 1967, p. 12

28）たと之ば，阿部政雄：坑内バクテリヤ・リーチングについて，同和鈆業 小坂鉱業所報告，昭和 46 年

29) A. W. Fletcher: ibid. 25)

30) J. B. Fletcher: Trans. SME, AIME, 250, 1971, pp. 310 314

\section{Technology for In Place Leaching}

by Ichiro ITO

The term "in place leaching" as used here designates a method for the in place extraction of metals from ores which have been left in a mine or from ore deposits which are consolidated or have not been disturbed through conventional mining methods.

The in place leaching technology is considered to be one of the most promising methods of utilizing the low grade ores in situ and will be employed in metal production to satisfy the ever increasing demands for metals.

In this article, the author summarized the results of the recent studies concerning the fundamental problems involved in the technology for the in place leaching and also described some of the practical applications of this technology for the real in situ deposits.

\section{バクテリヤ・リーチング文献集 $(\mathbf{I V})$}

\section{バクテリヤ・リーチング研究会 発行}

内 容 1. バクテリア・リーチング：その応用と理論への序論と作用機構に関する研究…… 染谷淳一郎 訳

2. バクテリア・リーチング機構に関する研究

3. 硫化亜鉛精鉣の微生物浸出に及ぼす炭酸ガスおよび粒子表面積の影響.

4. 酸化した硫化鉱物を主成分とし，錫を含有する精鉱からの砒素括よび 銅のバクテリアによる選択的リーチング：リーチングの機構

5. 合成したコバルト，ニッケルおよび亜鉛硫化物の Thiobacillus ferrooxidans

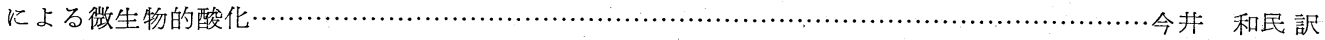

6. Thiobacillus fer rooxidans によるセレン化第二銅の酸化…..................................冨塚 登 訳

（既刊 文献集（I）500円，（II）500円，(III）600円の在庫もまります。）

《お申込みは本会事務局まで》 